\title{
20 LET ONLINE IZOBRAŽEVANJA NA DOBI
}

Besedilo, ki je pred vami, nima namena natančnega in izčrpnega prikaza razvoja online študija na DOBI, v njem želim obuditi nekaj točk spomina, ki so pomembne za nekatere temeljne ideje. Tudi zato, ker te še danes veljajo za izhodišča razvoja online izobraževanja.

Na DOBI smo oblikovali strategijo online študija, sprejeto na ključnih organih DOBE. Odločili smo se za najzahtevnejši model študija na daljavo v kombinaciji z e-izobraževanjem, in sicer za v celoti spletno podprto učenje - online učenje brez fizičnega stika med študentom in profesorjem. S celostno podporo študentom in sodobnimi pedagoškimi pristopi zagotavljamo visoko raven aktivnosti študentov, doseganje ciljev, kompetenc, učnih izidov ter sodobno preverjanje in ocenjevanje znanja.

Med študijem študentom ponujamo pedagoško, organizacijsko in tehnično podporo. Študente spremljajo profesorji in online mentorji. Vloga slednjih je predvsem motivacijska, študentom so na voljo 24 ur na dan sedem dni v tednu.

Model online študija na DOBI nas postavlja ob bok modelom online študija, ki veljajo za najbolj domišljene in kakovostne v svetovnem merilu. Oblikovali smo ga kot odgovor na potrebe po bogatitvi in povečanju dostopnosti izobraževalnega prostora v Sloveniji, kot odgovor na potrebe posameznikov po večji fleksibilnosti, individualizaciji, kakovosti njihovega znanja in kompetenc, kot podporo vseživljenjskemu učenju in ne nazadnje kot vnos svetovnih trendov v naš prostor.

\section{PREHOJENA POT}

DOBA je od ustanovitve v devetdesetih letih prejšnjega stoletja rasla in se razvijala. Skupaj s sodelavci smo iskali nove priložnosti za vnašanje inovativnosti v slovenski izobraževalni prostor. Razvijali smo izobraževane programe, izvajali jezikovne in srednješolske programe ter ustanovili prvo zasebno višjo strokovno šolo v Sloveniji. V devetdesetih je bila družbena naravnanost naklonjena tudi razvoju zasebnih izobraževalnih zavodov. To nas je navdajalo z optimizmom. Spremljali smo novosti v svetu in se navduševali nad novimi pristopi za večanje dostopnosti in fleksibilnosti izobraževanja ob podpori informacijske tehnologije. Mikalo nas je, da bi tudi na DOBI odraslim z drugačnimi pristopi omogočili večjo dostopnost izobraževanja. Zato sem predlagala, naj začnemo razvijati online študij, sodelavci so bili navdušeni. Oblikovali smo razvojnoprojektni tim, skupaj smo sedli Mateja, Ema in Rado. Vodenje tima je bilo zame pravi izziv, vsi člani smo bili zavzeti in željni novosti pri uvajanju drugačnih pristopov v izobraževanju ob zavedanju, da so inovacije generator spreminjanja v izobraževanju. 
Ko sem idejo predstavljala na takratnem ministrstvu za šolstvo in na Andragoškem centru Slovenije, so se nejeverno spogledovali in se spraševali, ali ima ta ideja v Sloveniji možnosti za uspeh.

Navkljub vsem dvomom smo staknili glave, pripravili analizo online študija v svetu, študirali literaturo, se vključevali v različna izobraževanja, obiskovali izobraževalne ustanove v Evropi, spoznavali modele, pripravili izhodišča za naš model z jasnimi cilji. Da, dve leti smo trdo delali pri projektu - to je še danes naš največji razvojni projekt - in uspelo nam je. Razvili smo DOBIN model online študija. Že od vsega začetka projekta smo postavljali v ospredje razvoj pedagoškega modela, ki bo nadomestil fizični kontakt med profesorjem in študentom. Za informacijsko podporo smo uporabili že obstoječa in ponujena orodja, ki so jih razvili na svetovnih univerzah.

\section{ŠTEVILO ŠTUDENTOV SE JE IZ LETA V LETA POVEČEVALO, TUDI NIIHOVO ZADOVOLJSTVO}

Študentje na DOBA Fakulteti in na Višji strokovni šoli so v glavnem zaposleni, večja je zastopanost žensk, povprečna starost je med 25 in 40 leti. DOBIN model online študija je najprimernejši za zaposlene, športnike in druge, skratka za tiste, ki zaradi službe in družinskih obveznosti ne morejo obiskovati predavanj.

Pred 20 leti smo na DOBI v ta edinstveni način študija vpisali prvih 30 študentov, ob ustanovitvi DOBA Fakultete pa smo model uspešno prenesli tudi v visokošolske programe na fakulteti.

Danes je v DOBIN model online študija vključenih prek 1200 študentov na leto, ki delajo in živijo v 46 državah sveta. Pri nas je diplomiralo že prek 7000 online diplomantov, ki uspešno prenašajo nova znanja $\mathrm{v}$ delovna okolja.

Zadovoljstvo študentov z izvedbo je visoko (ocena 6,7 na sedemstopenjski lestvici).

Uspešnost in napredovanje diplomantov skrbno spremljamo, saj so prav diplomanti ambasadorji kakovosti naše izobraževalne ustanove. Tako ugotavljamo, da kar 56 \% diplomantov po diplomi napreduje v karieri. Tudi delodajalci so naš pomembni partner. Povprašamo jih po zadovoljstvu z diplomanti. Najvišje ocenjujejo razvoj mehkih kompetenc pri diplomantih (sodelovanje, delo v timih, kritičnost, inovativnost, samoorganiziranost, reševanje problemov, inovativnost). To so pomembne kompetence 21. stoletja.

\section{RAZVILI SMO DOBIN MODEL ONLINE ŠTUDIJA}

Model online študija na DOBA Fakulteti je usmerjen $v$ študenta in kompetenčno zasnovan: $\mathrm{v}$ ospredju so študentje in njihove učne aktivnosti, ki so usmerjene v razvoj in krepitev kompetenc. Model študente spodbuja k aktivnemu sodelovanju v učnem procesu, skupnemu kreiranju novega znanja, izhajajočega iz njihovih izobraževalnih, socialnih in delovnih izkušenj, k sodelovalnemu učenju, ki ga podpiramo z različnimi aktivnimi 
metodami dela, kot so diskusije, študije primerov, reševanje problemov, projektno in timsko delo ter drugo.

To niso samo želje in zapisani cilji, tako dejansko poteka izvedba online študija na DOBI. Ob sprotnih aktivnostih si študentje sami določajo čas za učenje in učni tempo ter s podporo tehnologije dostopajo do učnih informacij in gradiv kjerkoli in kadarkoli.

Za kakovost izvedbe online izobraževanja je pomembno nenehno pedagoško inoviranje. Pedagoško inoviranje na DOBA Fakulteti razumemo kot spodbujanje, širjenje in razvijanje kulture inoviranja, in sicer na področju:

- inovativnih pedagoških pristopov,

- uvajanju inovativnih tehnologij,

- razvijanja inovativnih vsebin ter

- sodelovanja in povezovanja z vsemi deležniki.

Na DOBI se zelo zavedamo dejstva, da samo uvajanje tehnologije brez sodobnih pedagoških pristopov ne zagotavlja uspeha in da je lahko ob nestrokovni implementaciji za študente celo neprimerno. Pristop mora biti celosten, poleg pedagoških pristopov je med drugim pri online študiju treba uvesti tudi sodobnejše načine preverjanja in ocenjevanja znanja. Slednji izhajajo iz učnih ciljev predmeta, so integrirani v študijske aktivnosti študentov ter potekajo sproti s povratnimi informacijami in samoocenjevanjem.

V nasprotju z drugimi ustanovami terciarnega izobraževanja na DOBI že od vsega začetka največ pozornosti namenjamo podpori študentom v vseh fazah - pred študijem, med njim in po njem. Sistem podpore nenehno krepimo ter izgrajujemo skladno s potrebami in pričakovanji kandidatov, študentov in diplomantov v celoto, ki zajema pedagoško, organizacijsko, tehnično in administrativno podporo. Tako zastavljen celostni sistem podpore pomeni danes eno ključnih dodanih vrednosti DOBINEGA modela online študija, kot to prepoznavajo naši študentje in strokovnjaki s področja online izobraževanja $\mathrm{v}$ svetu.

Na DOBI se zavedamo, da ima lahko zanemarjanje spremljanja velikega napredka spoznanj o učenju in novih tehnologijah in njihovega uvajanja precejšnje negativne posledice. DOBIN model online izobraževanja zato nenehno dograjujemo in inoviramo. V 20 letih smo spremenili celoten pedagoški model v skladu z najnovejšimi dognanji pedagogike in visokošolske didaktike, spreminjali smo tehnologijo s poudarkom na krepitvi interaktivnosti med učitelji in študenti ter dogradili zagotavljanje varnosti pri preverjanju in ocenjevanju znanja.

\section{KAKOVOST SMO POTRJEVALI Z MEDNARODNIMI AKREDITACIJAMI}

DOBA je s svojim dinamičnim in nenehno razvijajočim se modelom online študija, ki sledi mednarodnim standardom kakovosti online izobraževanja, prepričala tudi strokovnjake. Je prva institucija v jugovzhodni Evropi, ki je pridobila mednarodni akreditaciji UNIQUE in EOCCS. 


\section{RAZISKAVE IN RAZVOJ SO VPETI V NAŠE POSLANSTVO}

Pozorno spremljamo učinkovite pedagoške prakse $\mathrm{v}$ svetu in se tudi sami intenzivno ukvarjamo z raziskovanjem in razvojem novih oblik in načinov poučevanja ter učenja.

Online izobraževanje je eno izmed temeljnih področij raziskovanja visokošolskih učiteljev in raziskovalcev na DOBA Fakulteti. Izvedli smo naslednje večje raziskovalne in razvojne projekte:

- Analiza stanja na področju digitalizacije in e-izobraževanja v visokem šolstvu,

- Osebnostne značilnosti in učno vedenje online študentov DOBA Fakultete,

- Uvedba učnih analitik v online izobraževanje na DOBI.

Od leta 2007 na DOBI deluje Svet za študij na daljavo/e-študij, ki z zunanjimi eksperti spremlja naše delo in predlaga ključne točke razvoja, od leta 2018 pa še Inštitut za e-izobraževanje. Njegovo poslanstvo je z raziskovalnim in razvojnim delom prispevati k nadaljnjemu razvoju in kakovosti online študija na DOBI ter h krepitvi DOBE kot nosilke in spodbujevalke tovrstnega študija v Sloveniji, z mednarodno prepoznavnostjo in ugledom.

V skladu z našo zavezanostjo odličnosti poučevanja in učenja v okviru Kompetenčnega centra na DOBI skrbimo za razvoj kompetenc za sodobno učenje in poučevanje pri vseh deležnikih fakultete.

\section{ONLINE ŠTUDIJ DANES IN NAŠ POGLED V PRIHODNOST}

Online izobraževanje je danes v svetu prepoznano kot kakovosten način izobraževanja, ki ponuja izobraževalne priložnosti vsem skupinam prebivalstva ter spodbuja razvoj znanja in spretnosti, ki so bistveni za obstoj in razvoj digitalne družbe. V ospredju ciljev online izobraževanja so ustvarjanje znanja s kritičnim razmišljanjem, povezovanjem, sodelovanjem in reševanjem problemov ter ustvarjanje in odprta uporaba digitalnih vsebin.

Informacijske tehnologije so pomemben vzvod inoviranja in prilagajanja v izobraževanju. Na DOBI se zavedamo, da se inovativnost v izobraževalnih ustanovah ne »zgodi« sama po sebi, je navdih, je kultura, ki jo gojimo in negujemo ter se $\mathrm{z}$ njo vsak dan poslovno in osebno razvijamo. Izvajanje in razvijanje online študija $v$ prihodnosti je za nas izziv. Zavedamo se nalog, ki so pred nami, in verjamem, da jih bomo izpeljali. Postavljamo si visoke in ambiciozne cilje, ki nas vodijo med vodilne izobraževalne ustanove glede na dobro prakso v EU na področju visokokakovostnega online izobraževanja. Usmeritve in cilje bomo tako kot doslej dosegali z motiviranimi in zavzetimi sodelavci. Imamo voljo, znanje, optimizem, energijo in veliko željo po novem, edinstvenem izobraževanju, kar je potreba za danes in za jutri.

Skrb zbujajoče pa je zaostajanje Slovenije na področju e-izobraževanja, posebej v visokošolskem sektorju. Na to opozarjajo mednarodne in domače raziskave. Izvajanje online študija na DOBI z mednarodnimi akreditacijami je za konkretnejši preboj e-izobraževanja v Sloveniji premalo, treba bo strniti moči in oblikovati novo strategijo. 
Danes skrbi na DOBI za razvoj in izvedbo online izobraževanje široka razvojna in strokovna ekipa: Irena, Marko, Vesna, Stanko, Teja, Zvezdana, Ksenija, Jure, Aneta. Ti sodelavci skrbijo za uvajanje pedagoških inovacij, za pedagoško podporo profesorjem, zadovoljstvo študentov. Za izvedbo je odgovornih 126 višješolskih predavateljev in visokošolskih učiteljev, ob sodelovanju 73 online mentorjev.

Naš slogan je: »razvijati nove stvari« in »razvijati obstoječe stvari na bolje«.

Jasna Dominko Baloh 